\title{
THE EFFECTIVENESS OF SCRAPMOD AS A LEARNING MEDIA TO IMPROVE STUDENTS' LEARNING OUTCOMES
}

\author{
Tiara Yusi Destari ${ }^{1^{*}}$ dan Rusly Hidayah ${ }^{\mathbf{1}}$ \\ ${ }^{1} J u r u s a n$ Kimia, Fakultas Matematika dan Ilmu Pengetahuan Alam, Universitas Negeri \\ Surabaya, Jl. Ketintang Kecamatan Gayungan, Surabaya, 60231, Indonesia \\ *Email: tiaradestari@mhs.unesa.ac.id
}

\begin{abstract}
ABSTRAK
Penelitian ini bertujuan untuk mengetahui pengaruh Scrapmod yaitu suatu media pembelajaran yang merupakan gabungan dari scrapbook dan moly mod terhadap peningkatan hasil belajar kognitif peserta didik pada materi bentuk molekul. Penelitian ini menggunakan metode R\&D (Research \& Development) yang dilakukan hanya sampai uji coba terbatas. Uji coba media yang dilakukan menggunakan rancangan penelitian one group pretest-posttest design. Nilai pretest dan posttest yang diperoleh harus dinormalisasi menggunakan tes Kolmogorov Smirnov, kemudian dianalisis nilai N-Gain untuk mengetahui peningkatan hasil belajar kognitif setiap peserta didik. Hasil belajar kognitif peserta didik dikatakan meningkat apabila nilai posttest lebih besar dari pada nilai pretest. Uji coba dilaksanakan kepada 33 peserta didik kelas XI SMAN 1 Porong, Sidoarjo. Metode pengambilan data dilakukan dengan cara angket, observasi, dan tes. Persentase rata-rata skor $\mathrm{n}$-gain yang diperoleh adalah 0,6 yang artinya masuk ke dalam kategori sedang. Hal ini menunjukkan bahwa penggunaan Scarpmod sebagai media pembelajaran pada materi bentuk molekul memberikan respon positif yaitu dapat meningkatkan hasil belajar kognitif peserta didik.
\end{abstract}

Kata kunci: hasil belajar kognitif, media pembelajaran, scrapmod

\begin{abstract}
This study aims to determine the effect of scrapmod which is a learning media which is a combination of scrapbook and moly mod to improve cognitive learning outcomes of students on molecular geometry. This study uses an $R \& D$ method (Research \& Development) which is conducted only to a limited trial. The limited trials were conducted using a one-group pretest-posttest design. The pretest and posttest values obtained must be normalized using the Kolmogorov Smirnov test, then the N-Gain value is evaluated to obtain the improvement in cognitive learning outcomes of each student. Cognitive learning outcomes of students discussed increased if posttest values are greater than the pretest. The limited trial was conducted on 33 students of class XI of SMAN 1 Porong, Sidoarjo. The method of collecting data is done by using questionnaires, observations, and tests. The average percentage of the $\mathrm{N}$-Gain score obtained is 0.6 , which means it falls into the medium category. This shows that the use of scarpmod as a learning media on molecular geometry gives a positive response that can improve students' cognitive learning outcomes.
\end{abstract}

Keywords: cognitive learning outcomes, learning media, scrapmod

DOI: http://doi.org/10.15575/jtk.v4i2.5849 


\section{INTRODUCTION}

Education is one of the means to form the nation's next-generation quality in the future (Kumayati, 2014). One effort to improve quality school education is providing a fun learning for students, not least in chemistry learning. Fun learning is a learning process that is on inside there is a cohesion strong between teachers and students without feeling forced or depressed (Mulyasa, 2006). Besides that, Fibriani et al. (2014) stated that in the teaching and learning process, two very important elements are teaching methods and learning media. Examples of studies that show that fun learning and learning media are needed to improve cognitive learning outcomes of students is in research by Kumayati (2014), in this research using bolamod media that can improve learning outcomes on hydrocarbon subject matter in Raudhotul Tholibin Demak Islamic High School.

Chemistry the science of looking for answers for what, why, and how the symptoms of nature relating to composition, structure, and properties, changes, dynamics, and is substance energetics. Chemical concepts that abstract, it makes students are less motivated and able to affect the cognitive achievement of students (Kumayati, 2014). One of them is a chemical matter about molecular geometry. Molecular geometry is an important subject in comprehending the substance correctly since it has a significant role in the determination of the physical and chemical properties of a molecule (Uyulgan et al., 2014). The geometry of a molecule can be explained by the arrangement of all-electron pairs, bonding pairs and lone pairs on the skin of the valence of the central atom (Gillespie, 2004). It can determine that molecular geometry can be based on VSEPR (Valence Shell Electron Pair Repulsion) theory. This assumption to the wellknown geometry for $A X_{\mathrm{n}} E_{\mathrm{m}}$ molecules, where $A$ is the central atom, $X$ is a ligand, and $E$ is a lone pair (Gillespie, 2004). Molecular geometry matter is one of the difficult and boring chemicals. This is due to the fact that molecular geometry matter is one of the abstract chemical matters and it takes a good imagination from students to imagine a molecular geometry. This is different from the results based on interviews with grade XI students in Senior High School 1 in Porong, Sidoarjo, the teacher in explaining the molecular geometry matter only uses a blackboard as a media to describe the geometry of molecules in one dimension. It makes students still have difficulty in imagining the geometry of molecules. So to make it easier for students to learn abstract chemistry, learning media is certainly needed.

Arsyad (2013) stated that the word media comes from Latin which means "middle", "intermediary", or "introduction". In Arabic, the media is an intermediary or delivery message from the sender to the recipient of the message. Broadly speaking, teachers, textbooks, and school environments are media. More specifically, the notion of media in the teaching and learning process tends to be interpreted as graphical, photographic, or electronic tools for capturing, processing, and compiling visual or verbal information. Media is anything that can be used to channel messages from the sender to the recipient, to stimulate the thoughts, feelings, attention, and interests and attention of students in such a way, so that the learning process occurs (Sadiman et al., 2010). Furthermore, Fibriani et al. (2014) stated that in the teaching and learning process, two very important elements are teaching methods and learning media. One of the main functions of learning media is as a teaching aid that also influences the climate, conditions and learning environment that is organized and created by the teacher. The use of media has a purpose to provide motivation, stimulate students to 
remember what was learned and helped students in understanding learning. Media a good one will also activate students in giving feedback and also encourages students to apply to learn in everyday life.

Therefore, one way to encourage the achievement of effective learning, especially in the geometry of molecular matter, is to use other learning aids, especially threedimensional media. The media that is usually used in molecular geometry matter is moly mod, but the fact in the field shows that there are still students who are not familiar with moly mod. Also, there are many studies on other learning media used in molecular geometry matter, for example, research by Dabke and Gebeyuhe (2010) regarding molecular geometry media made from magnets, paper clips, and ball bearings. He stated that the molecular geometry of the magnetic model could help in explaining the molecular geometry matter based on the VSEPR theory and the molecular geometry of some inorganic compounds. This research was conducted in a class consisting of more than 70 students and received positive feedback.

On the other hand, researchers see that there are currently several handicrafts that are in demand by adolescent children, one of which is a scrapbook. The scrapbook is the art of attaching photos or pictures on paper media and decorating them to become creative works. Based on this, researchers will develop an instructional media that combines moly mod and scrapbook called Scrapmod. This media will be expected to increase motivation and can help students in learning the molecular geometry of learning so that it can have a positive impact on student learning.

The researcher makes Scrapmod as a molecular geometry learning media. This media is made to visualize molecular geometry in three dimensions to help students distinguish between one another's molecular geometry so that students better understand the subject matter of this molecule. The Scrapmod media is a combination of moly mod and scrap-box. Scrapmod is a box of sized art carton paper $15 \times 15 \mathrm{~cm}^{2}$. The Scrapmod box can be opened from the top and the left side will open immediately. On all four sides there are periodic tables, how to determine molecular geometry based on VSEPR theory, information from elemental atomic balls, steps to determine molecular geometry based on VSEPR theory, molecular geometry from coordination number 2 to 6 , and in the middle there is a tube containing modeling of elemental atoms. For modeling, the molecular geometry of compounds used elemental balls of styrofoam and spiral wire in the tube. Each element atomic ball has a different color according to the number of holes and their respective functions. The bond between the central atom and the atoms bonded to the Scrapmod media is spiral wire. In this model two types of wire are provided, namely: 1) Both edges are sharp and 2) One end is blunt. Spiral wire with sharp edges shows a single bond, while spiral wire with one blunt end shows a free electron pair. This spiral wire is wrapped using paper that has a different color. Spiral wire with two sharp edges wrapped in blue paper, while spiral wire with one end blunted with red paper. Scrapmod is also equipped with the first guidebook. The contents of the first guidebook are a brief description of Scrapmod. Second is the step for using the media. These steps are equipped with pictures showing the parts of the media and their explanations so that the user is clearer and more understanding in using Scrapmod. The third is the plan for implementing learning or lesson plans. Fourth is the key answer to the practice questions contained in Scrapmod. 
Scrapmod has advantages compared to moly mod or other media on the market, such as molecular geometry media from plasticine or plastic balls, namely Scrapmod packaged more innovative, creative, and interesting and equipped with tutorials on how to determine molecular geometry based on VSEPR theory and practice questions about molecular geometry matter affixed to the sides of Scrapmod. From the previous explanation, it can be seen that long before the existence of Scrapmod learning media, there was already a scrapbook which was the art of attaching photos on paper media in the form of books or albums. Along with the development of the times, there are other forms of scrapbook in the form of boxes. People call it the name scrapbox. Based on the pre-research results on moly mod and scrap-box, researchers combined moly mod and scrap-box into a learning media to help students learn about moleculargeometry matter called Scrapmod.

\section{RESEARCH METHODOLOGY}

This research uses the R\&D (Research and Development) method. The steps of research and development consist of three stages, among others: 1) Preliminary study, 2) Media development, and 3) Media test (Sukmadinata, 2016). It conducts just until media development, namely the limited trial stage. This research was carried out until the limited trial stage. The limited media trials carried out using the one-group pretest-posttest design, namely before students using Scrapmod will be given the pretest questions about the molecular geometry and after using Scrapmod will be given a posttest question about the molecular geometry.

According to Sukmadinata (2016), development research involved 6-12 people, so that this study was limited to only 12 students who had obtained molecular geometry matter.
Media will be tested to 12 students of class $X$ of senior high school 1 in Porong, Sidoarjo who have obtained molecular geometry matter. The 12 students were selected based on the values that students had obtained in the molecular geometry matter, then 3 people with low values were chosen, 6 people with middle values, and 3 people with high values (Sudjana, 2006).

The first step is a preliminary study. In the preliminary study, the phase consists of three steps, namely literature study, field surveys, and preparation of the initial draft. A literature study is a study to study concepts or theories related to the media. This stage will examine learning theories that support learning using media, good learning media criteria, and the character of students at high school age. The literature study also examines the results of previous research on the use of media in the learning process.

Next up is a field survey. This step is carried out to collect data related to product planning. The field survey was conducted at Senior High School 1 in Sidoarjo by giving pre-research questionnaire sheets to 33 students of class $\mathrm{XI}$. Besides, interviews were also conducted with one chemistry teacher about the media, facilities, learning resources of students, and analysis of students. The results of interviews and pre-research questionnaires were used as the basis for choosing Scrapmod as a learning media on molecular geometry matter.

Based on data obtained from literature studies and field surveys, preparation of the initial draft begins. The first thing to do to design a media is to formulate learning objectives. The second is to prepare the initial draft of the media. Sticking to the data obtained from the field survey and referring to the basics or concepts about media, theories that support learning using media, molecular geometry matter and the results of previous research on the use of 
instructional media, the researchers compiled an initial draft of the media.

After that proceed to the second stage of media development. This stage is carried out to produce Scrapmod which can be used as a learning media based on the results of a review by experts. Media that have been reviewed and validated will then be tested on a limited trial to 12 students in class $X$ high school who have received molecular matter. The limited trial was carried out in the Senior High School 1 in Porong, Sidoarjo. The trial was conducted on 27 and 28 March 2019. The trial was conducted in two meetings, namely three times 45 minutes of class time. The pretest and posttest results obtained were used to find out the effectiveness of the developed media by looking at the improvement in cognitive learning outcomes before and after using Scrapmod media in learning molecular geometry. At the first meeting which is $1 \times 45$ minutes long, before the trial use of Scrapmod, students will be given a pretest in the form of 10 questions about the matter in molecular geometry. Then the authors explain how to use Scrapmod.

At the second meeting, students will work on the multiple choice practice questions in the Scrapmod in $2 \times 45$ minutes. The work of students is then presented by each group. Then posttest is done by doing 10 questions about the matter in molecular geometry. After posttesting, students are given a questionnaire response sheet about the interest, clarity, and ease of Scrapmod and the level of motivation of students in using Scrapmod. Pretest questions, posttest questions and questionnaires were validated by two chemistry lecturers and the results of the validity of the questions and questionnaires were valid. Also, during the learning process using Scrapmod, both at the first meeting and the second meeting, the activities of the students will be observed by three observers. Each observer will observe four students in a group.

Before the results of the pretest and posttest values are calculated by gain, the value data of students are tested for normality first to determine the data obtained has been normally distributed. The purpose of normally distributed data is that the data will follow the form of a normal distribution where data is centered on the average and median values (Kariadinata and Abdurahman, 2012). The normality test was carried out using SPSS version 16.0 with the Kolmogorov-Smirnov test which showed that the data obtained were normally distributed with $\alpha=0.05$. If Asymp. Sig. obtained $>0.05$ then the data does not have a significant difference, so it can be concluded that the data has been normally distributed. After being tested for normality and declared a normal distribution, the gain can be calculated using the gain formula which is as follows:

$$
\begin{array}{r}
\operatorname{gain}(g)=\frac{(\text { posttest vale }- \text { pretest value })}{(1)} \\
\text { (Meal value }- \text { pretest value }) \\
\text { (Meltzer, 2002) }
\end{array}
$$

\section{RESULTS AND DISCUSSION}

The effectiveness of Scrapmod is obtained from the results of the tests of each student and was assessed by increasing the pretest and posttest value. The pretest is carried out before students use Scrapmod and the posttest is carried out after students use Scrapmod. Increasing the pretest and posttest values then analyzed using the normalized gain value. Scrapmod is declared effective if students who take part in a limited trial a gain of $\geq 0.3$ or fall into the medium or high category. Pretest and posttest data results must be tested for normality first to find out whether the data taken is normally distributed data or not. Data is said to be normally distributed if it gets $\alpha>0.05$. After the normality test and declared a normal distribution, the gain value can be calculated. 
The Effectiveness of Scrapmod as a Learning Media to Improve Students Learning Outcomes

Before using the developed Scrapmod, students are given a pretest to find out the initial abilities students have about molecular geometry matter. This value was analyzed using the normalized gain value. The results of the students' pretest are shown in Table 1.

Table 1. Student's Pretest Value Results

\begin{tabular}{|c|c|c|}
\hline Nu. & Name & Value \\
\hline 1. & Student 1 & 17.86 \\
\hline 2. & Student 2 & 14.29 \\
\hline 3. & Student 3 & 28.57 \\
\hline 4. & Student 4 & 0 \\
\hline 5. & Student 5 & 7.14 \\
\hline 6. & Student 6 & 35.71 \\
\hline 7. & Student 7 & 42.86 \\
\hline 8. & Student 8 & 28.57 \\
\hline 9. & Student 9 & 64.29 \\
\hline 10. & Student 10 & 28.57 \\
\hline 11. & Student 11 & 28.57 \\
\hline 12. & Student 12 & 42.86 \\
\hline
\end{tabular}

The results of the pretest are then tested for normality to determine whether the data obtained is normally distributed or not. Based on the results of the normality test using SPSS version 16.00, the results obtained that the pretest data obtained were normally distributed because of the value of Asymp. Sig. (2-tailed) is 0.831 . This value is $0.831>0.05$, so it can be said that the pretest value has a normal distribution, meaning that there is no significant difference from the pretest data obtained.

After the trial process uses Scrapmod media, then students are given a posttest to find out the improvement in students' abilities after using Scrapmod on molecular geometry matter. Posttest data results are presented in Table 2.
Table 2. Student's Posttest Value Results

\begin{tabular}{|c|c|c|}
\hline Nu. & Name & Value \\
\hline 1. & Student 1 & 71.43 \\
\hline 2. & Student 2 & 57.14 \\
\hline 3. & Student 3 & 64.29 \\
\hline 4. & Student 4 & 32.14 \\
\hline 5. & Student 5 & 75.00 \\
\hline 6. & Student 6 & 78.57 \\
\hline 7. & Student 7 & 82.14 \\
\hline 8. & Student 8 & 82.14 \\
\hline 9. & Student 9 & 75.00 \\
\hline 10. & Student 10 & 82.14 \\
\hline 11. & Student 11 & 75.00 \\
\hline 12. & Student 12 & 82.14 \\
\hline
\end{tabular}

The results of the students' posttest values showed that all the values of the students had increased compared to the values of pretest previously obtained, but the increase in each child was different. If analyzed from the answers on the posttest sheet, the questions that are answered incorrectly by students are C1 type questions, namely remembering. In this type of problem, students are asked to name the molecular geometry of a compound whose PEI and PEB are known. Although during the experiment using Scrapmod, various types of molecular geometry have been studied by modeling using elemental atomic spheres, but students still have difficulty determining and distinguishing the names of molecular geometry from one another. Inversely proportional to the type of question $\mathrm{C} 4$ that is analyzing, the average student has increased compared to the answers on the pretest questions. In this type of problem, students are asked to analyze a type of molecular geometry of a compound with the known atomic number or electron configuration. The average student answers correctly on this type of problem for the posttest problem, because in Scrapmod media also comes with steps and ways to determine the molecular geometry of a compound. The posttest results are then tested for normality. Based on the results of the normality test using SPSS, the results show that 
the posttest data results are normally distributed, because of the Asymp. Sig. (2tailed) equal of 0.592 , which means this result is $0.592>0.05$. By using a confidence rate $\alpha>$ 0.05 , it means that the data obtained did not have a significant difference, and it was concluded that the posttest results were normally distributed. The comparison of the pretest and posttest is followed in Figure 1.

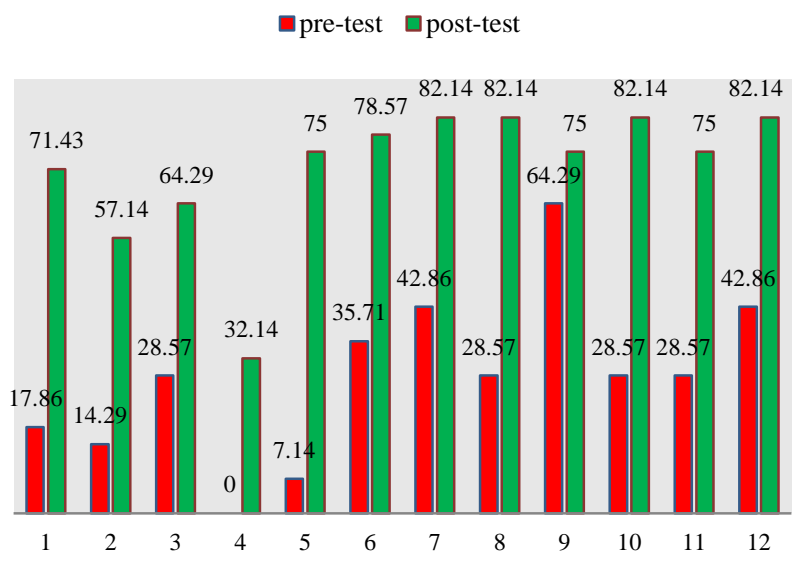

Figure 1. Comparison of pretest and posttest value

Based on the results of the pretest and posttest values that have been tested and stated to have been normally distributed, then the gain value can be calculated to determine the increase in student learning outcomes after using Scrapmod media on molecular geometry matter. The $\mathrm{n}$-gain data is shown in Table 3.

Table 3. The $n$-gain Value's Calculation

\begin{tabular}{|c|c|c|c|c|}
\hline Name & $\begin{array}{c}\text { Pretest } \\
\text { value }\end{array}$ & $\begin{array}{c}\text { Posttest } \\
\text { value }\end{array}$ & $\begin{array}{c}\text { N-gain } \\
\text { Value }\end{array}$ & Category \\
\hline Student 1 & 17.86 & 71.43 & 0.7 & High \\
\hline Student 2 & 14.29 & 57.14 & 0.5 & Medium \\
\hline Student 3 & 28.57 & 64.29 & 0.5 & Medium \\
\hline Student 4 & 0 & 32.14 & 0.3 & Medium \\
\hline Student 5 & 7.14 & 75 & 0.7 & High \\
\hline Student 6 & 35.71 & 78.57 & 0.7 & High \\
\hline Student 7 & 42.86 & 82.14 & 0.7 & High \\
\hline Student 8 & 28.57 & 88.14 & 0.7 & High \\
\hline Student 9 & 64.29 & 75 & 0.3 & Medium \\
\hline Student 10 & 28.57 & 82.14 & 0.7 & High \\
\hline Student 11 & 28.57 & 75 & 0.7 & High \\
\hline Average & 28.27 & 71.43 & 0.6 & Medium \\
\hline
\end{tabular}

Based on the method used in this study, the first stage is preliminary study includes literature studies, field surveys, and preparation of the initial draft. The researchers found that students who are studying in high school have an age range of 11 years. Based on Piaget's Learning Theory, at that age cognitive students have started formal operations. In this student, it will be easier for students to challenge abstract or symbolic matters, but the fact is that students have not reached this point, media is needed as an aid to facilitate students in building their knowledge and looking for information that can be obtained more useful. Besides, researchers examined previous studies related to the development of Scrapmod as a learning media on the molecular matter. Based on previous studies, the results show that the use of three-dimensional media such as Scrapmod as a learning media on molecular geometry matter can have a positive effect on student achievement compared to conventional learning.

Based on the results of the posttest value of students show that all grades of students have increased compared to the pretest values obtained before, but the increase in each child varies. Besides, from the pretest and posttest value, it can be seen that the average learning outcomes of students in the analysis of $\mathrm{N}$-gain values indicate an increase of 0.6 which falls into the medium category. Most students experience an increase in learning outcomes in the high category, only four people are in the medium category. Two of them gained 0.3 which is a minimum gain value in the medium category. If analyzed from the posttest answers of the two students who gained 0.3 each child has different problems.

For students 4 get a gain of 0.3 . Although the posttest value obtained increased compared to the value of the pretest, the increase was not too significant and the pretest value obtained 
was 0 . This indicates that students' initial knowledge of the matter in molecular geometry can be said to be very lacking. For students 9 also gained 0.3 , because the increase in the posttest value compared to the pretest value was also not significant. Even so, the value of the pretest of 9 students was quite good, but only slightly increased for the posttest value.

Overall, there is a significant difference between pretest and posttest (there is an increase) of student learning outcomes about the matter in geometry of molecules. This shows that media that meet the $n$-gain value in the medium or high category can improve and achieve learning goals (Limatahu et al., 2018). It means that $100 \%$ of students experience an increase in learning outcomes when viewed from the value of the pretest and posttest. Thus, the Scrapmod media can be declared feasible as a learning media from an effective aspect. This is following what was mentioned by Hake (1998) regarding gain categories, a media is said to be feasible from the aspect of effectiveness if the learning outcomes of students experience an increase in learning in the medium and high categories.

Based on a study by Dabke and Gebeyuhe (2010) regarding molecular geometry media made from magnets, clip paper, and ball bearings stated that the use of this media in molecular shape matter based on VSEPR theory received positive feedback from more than 70 participants. This is following the research on the development of Scrapmod media on molecular form matter based on VSEPR theory, namely $100 \%$ of 12 students experienced an increase in learning outcomes after using Scrapmod media by gaining an average gain of 0.6 and entering into the medium category. This means that the use of Scrapmod media gets positive feedback from all students who take limited trials.
Following the data and research results obtained from the limited trial of Scrapmod media in Senior High School 1 in Porong, it can be concluded that Scrapmod media can be said to be feasible as a learning medium because it has fulfilled the aspects of validity, practicality aspects, and effectiveness aspects. This is following what was said by Plomp and Nieveen, namely a product that is said to be of quality if it has three criteria which include validity, practicality, and effectiveness (Plomp and Nieveen, 2013). The development of Scrapmod is shown in Figure 2.

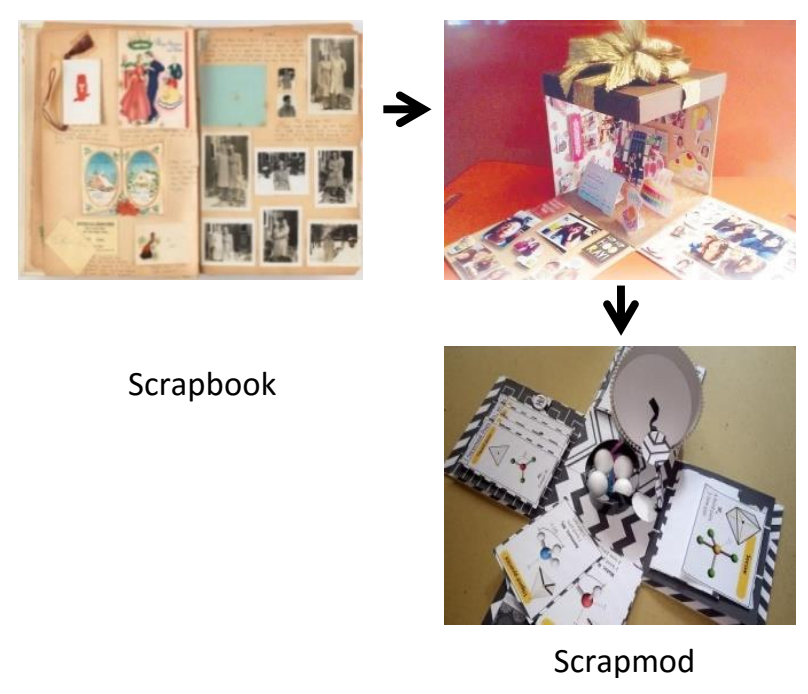

Figure 2. The development of Scrapmod

\section{CONCLUSION}

Based on the results of the limited Scrapmod trial by giving the pretest and posttest questions to the students, the average n-gain value was obtained by 0.6 with the medium category. This shows that the learning outcomes of students can be said to increase after using Scrapmod media as a learning media in molecular geometry matter.

From this study it can be concluded that the Scrapmod media can be effective as a learning media on molecular geometry. This study also 
has several limitations, both in terms of the implementation of limited trials as well as the appearance of the Scrapmod media itself. The use of time allocation must be strictly approved in the media trial, so that students can provide maximum molecular geometry and can be completed precisely at the time of the meeting. In addition, after using this media, Scrapmod must be stored in a place far from the water because the material used is paper. 


\section{REFERENCES}

Arsyad, A. (2013). Media pembelajaran. Jakarta: PT. Raja Grafindo.

Dabke, R. B. \& Gebeyuhe, Z. (2010). Using Magnets, Paper Clips and Ball Bearings to Explore Molecular Geometries. Journal of Cologe Science Teaching, 40(2), 70.

Fibriani, L., Damris, M., \& Ristina. (2014). Pengembangan Multimedia Pembelajaran Interaktif untuk Meningkatkan Motivasi dan Hasil Belajar Siswa pada Materi Kesetimbangan Kimia SMA. Edu-Sains, 3(1), $1-2$.

Gillespie, R. J. (2004). Teaching molecular geometry with the VSEPR model. Journal of Chemical Education, 81(3), 298.

Hake, R. R. (1998). Interactive-engagement versus traditional methods: A six-thousandstudent survey of mechanics test data for introductory physics courses. American journal of Physics, 66(1), 64-74.

Kariadinata, R., \& Abdurahman, M. (2012). Dasar-dasar statistik pendidikan. Bandung: Pustaka Setia.

Kumayati. (2014). Efektivitas penggunaan bolamod sebagai media pembelajaran materi pokok hidrokarbon kimia di SMA Islam Raudlotut Tholibin Demak tahun ajaran 2013/2014. Semarang: Institut Agama Islam Negeri Walisongo.

Limatahu, I., Wasis, Sutoyo S., \& Prahani, B. K. (2018). Development of Ccdsr Teaching Model to Improve Science Process Skills of Pre-Service Physics Teachers. Journal of Baltic Science Education, 17(5), 823.
Meltzer, D. E. (2002). The relationship between mathematics preparation and conceptual learning gains in physics : A possible "hidden variable" in diagnostic pretest scores. American Association of Physics Teachers, 70(12), 1260.

Mulyasa, E. (2006). Menjadi guru profesional menciptakan pembelajaran kreatif dan menyenangkan. Bandung: Remaja Rosdakarya Offset.

Plomp, T., \& Nieveen, N. (2013). Educational design research. Netherland: SLO, Netherlands Institute fro Curriculum Development.

Sadiman, A., Rahardjo, R., Haryono, A., \& Rahardjito. (2010). Media pendidikan: pengertian pengembangan dan pemanfaatannya. Jakarta: PT. Raja Grafindo Persada.

Sudjana. (2006). Metode statistik. Jakarta: Rineka Cipta.

Sukmadinata, N. S. (2016). Metode penelitian pendidikan. Bandung: PT Remaja Rosdakarya.

Uyulgan, M. A., Akkurzu, N., \& Alpat, S. (2014). Assessing The Students' Understanding Related To Molecular Geometry Using A Two-Tier Diagnostic Test. Journal of Baltic Science Education, 13(6), 839-840. 